УДК: 339.94(477:438)

JEL Classification: 05

B. B. РСЗНIКОВ,

кандидат економічних наук, дочент кафедри міжнародних економічних відносин, Харківський національний університет імені В. Н. Каразіна Ю. О. СЛФIMOBA,

бакалавр з міжснародних економічних відносин, Харківський національний університет імені В. Н. Каразіна

\title{
Співпраця між Украӥною та Республікою Польща: економіко-дипломатичний аспект
}

Єтан та перспективи економіко-дипломатичних відносин між Украйною та Республікою Польща досліджено шляхом аналізу документів, пов'язаних із дипломатичною та економічною співпрацею між двома крайнами після здобуття ними політичної незалежності, а також статистичних даних про взасмну торгівлю товарами і послугами та взаємні прямі інвестицій.

Ключові слова: співпрачя, дипломатія, торгівля товарами, експорт, імпорт, інвестиції.

Постановка проблеми. Республіка Польща $є$ не тільки одним із західних сусідів, а й стратегічним партнером України, з яким Україну поєднують довгі роки снівпраці. Серед країн Центральної та Східної Європи, які входять до Європейського Союзу (ЄС), це найбільш послідовний та дієвий партнер України. Після проголошення незалежності обидві країни вийшли на новий рівень відносин, які набули іншого характеру в умовах членства Польщі у ЄC.

Україна у своїх прагненнях до європейської інтеграції бачить у Польщі надійного економічного і політичного партнера. Тому факти і статистичні дані, що відображають якісні та кількісні аспекти українсько-польських відносин, мають бути предметом постійного моніторингу та аналізу, що допоможе своєчасно вирішувати проблемні моменти у відносинах цих країн.

Метою статті $\epsilon$ аналіз стану та перспектив економіко-дипломатичних відносин між Україною та Республікою Польша.

Аналіз досліджень і публікацій. Дослідженням питань співпраці між Україною та Польщею займалися А. Киридон, О. Біланюк, О. Свсюкова, О. Слісєєва, К. Кондратюк, В. Гевко, С. Стоєцький, Н. Павліха, В. Корчун, Я. Ошуркевич, М. Яцків та інші.

Внклад основного матеріалу дослідження. У сучасних умовах дипломатія $\epsilon$ складовою та органічною частиною зовнішньої політики бу дь-якої держави. Зовнішня політика країни визначає цілі та завдання дипломатії, яка являє собою сукупність практичних заходів, а також форм, засобів і методів, що використовуються для їі реалізації. Дипломатія і зовнішня політика складають єдине й неподільне ціле, дві сторони одного й того ж процесу. Розвиток міжнародних, у тому числі економічних, відносин сприяє залученню у цю сферу нових галузей суснільної діяльності [13].

3 розвитком спеціалізованих міжнародних відносин дипломатична діяльність стала набувати рис міждержавного регулювання економіки та реалізації зовнішньоекономічної політики держави. 3'явилося таке поняття як “економічна дипломатія", яке також має велику кількість трактувань. 3 одного боку, її визначають як досягнення економічних цілей засобами дипломатії, незалежно від того, вдається вона чи ні до економічних важелів заради їх досягнення [5, с. 52], з іншого - як діяльність 3 реалізації національних економічних інтересів на світовін̆ арені та захисту економгіної безпеки дипломатичними методами $[9$, с. 35].

Основи нової моделі українсько-польської снівпраці закладено у 90-х pp. XX ст., чому сприяли, насамперед, геополітичні зміни, які відбулися в Євроні: завершення "холодної він̆ни", припинення існування системи Варшавського договору, розпад Радянського Союзу, здобуття Україною та Польщею політичної незалежності. Вста-

(С В. В. Резніков, Ю. О. Слфімова, 2017 


\section{СПІвПРАЦЯ МІЖ УКРАЇНОЮ ТА РЕСПУБЛІКОН ПоЛЬЩА: ЕКОНОМКК-ДИПЛОМАТИЧНИЙ АСПЕКТ}

новленню новноцінних відносин сприяли також чинники географ)ічного, історичного, культурного, економічного та політичного характеру, зокрема геополітичне розташування, територіальна близькість, економічпі та культурні зв'язки, взаємний інтерес до співпраці. У жовтпі 1990 року було підписано українсько-польську Декларацію про дружбу і співпрацю, яка мала всі ознаки міждержавного договору: вона закріпила непорушність кордону між країнами і констатувала відсутність територіальних претензій між сторонами. Республіка Польща була фактично першою країною, яка офіцін̆но визнала державну незалежність України 2 грудня 1991 року. За часи незалежності України відносини між двома державами трансформувалися в тісну політичну, економічну, наукову та культурну співпрацю [3].

Подальшому розширенню двосторонніх відносин між країнами сприяла Декларація про приншипи та основні напрями розвитку українсько-польських відносин від 13 жовтня 1993 року. Нею передбачено заснування торговельних представництв, що виводило економічпі відносини між двома країнами-партнерами на новий рівень, а також конкретно визначено торговельно-економічні завдання в рамках співпраці.

Базовим документом українсько-польської співпраці є Договір між Україною і Республікою Польща про добросусідство, дружпі відносини і співпрацю, який підписаний під час візиту Президента України Л. Кравчука до Польщі 18 травня 1992 року й набув чинності 30 грудня 1992 року. Того ж 18 травня 1992 року підписано низку домовленостей та угод міжгалузевого рівня, у тому числі таких, що безпосередньо спрямовапі на створення договірно-правової бази українсько-польських торговельноекономічних відносин, зокрема про:

$>$ про економічну й науково-технічну співпрацю;

$>$ про економічну, науково-технічну та виробничу снівпрацю між міпістерствами сільського господарства України та Польщі;

$>$ про пункти пропуску через державний кордон;

$>$ про міжнародні автомобільпі перевезення.

Як результат, обсяг торгівлі товарами між Україною та Польщею значно зріс у 1992 році порівняно 3 попередпіми роками [1].

Вступ Польщі до СС створив для України нову реальність: серед його члепів уперше з'явилася країна, яка підтримувала й лобіювала українсыкий курс на членство в ЄC, а також у НАТО. Водночас постала потреба істотної модерпізації структури та наповнення політичного діалогу між Україною та Польщею. Так 2005 рік було проголошено роком України в Республіці Польща. За участі Президента України Україною й Польщею було підписано угоди про академічне визнання документів про освіту та наукові ступепі і про співпрацю у сфері інформатизації. Це надало поштовх розширенню торговельно-економічних та науково-техпічних зв язків між двома країнами, транскордонної співпраці в рамках створених у середипі 1990-х рр. єврорегіопів "Карпати" i "Буг".

Водночас практично у всіх сферах двосторонніх відносин позначилися проблеми, пов'язані зі входженням Польщі до Шенгенської зони. Це зумовило нові процедури й правила перетину українько-польського кордону й, відповідно, створювало додаткові трудноші для розвитку й оптимізації співпраці між двома країнами. Разом із тим Польща пішла на максимальне спрощення усіх адміністративних процедур, а також заявила, що й надалі наполягатиме на спрощенні візового режиму між ЄС та Україною [6]. Тому зараз ми знаходимось на шляху лібералізації візового та торгівельного режиму до країн $\mathrm{CC}$.

Одним із головних документів, що регулює відносини між Україною та Польшею у економічпій сфері, є Угода між Кабінетом Міністрів України та Урядом Республіки Польща про економічну співпрацю, підписана 4 березня 2005 року і ратифікована Верховною Радою України 15 березня 2005 року. Угода передбачає сприяння розвитку взаємовигідної економічної співпраці в усіх галузях і секторах економіки на принципах рівності і взаємної вигоди відповідно до законодавства держав - договірних сторін.

28 лютого 2006 року Президенти України та Польщі підписали першу спільну декларацію про розвиток співпраці в галузі енергетики. Співпраця в галузі енергетики - це саме те, що у майбутньому могло б добре розвиватися, дуже сильно поєднало $б$ економіки двох країн та надало б Україпі необхідну диверсифікацію джерел енергії [8].

Важливим напрямком розвитку двосторонніх відносин стало ініціювання Польщею активізації східного вектора в політиці ЄС. Так, у 2008 році під час зустрічі міністрів закордонних справ ЄС, Польщі і Швеції було представлено загальну пропо- 
зицію щодо поглиблення східного напрямку політики $Є С$, яка отримала назву “- Східне партнерство СС" (СП). Ініціатива СП адресована шести країнам - Україні, Молдові, Грузії, Азербайджану і Вірменії, а також передбачає технічну й експертну снівпрацю 3 Білоруссю. Тобто це конкретний інструментарін̆, який дозволяє ЄС реалізовувати інтеграційні проекти на теренах визначених країн.

На перспективності економічної снівпраці між Україною та Польщею було наголошено в рамках проведення Першого Міжнародного інвестиційного форуму "Україна: нові можливості" (22-24.04.2008). У рамках роботи форуму проведено 9 тематичних секційних засідань 3 питань енергетики, діяльності місцевих органів влади, розвитку інфраструктури, сільського господарства, принципів програми "Східне партнерство". Цього ж року було підписано низку інших договорів, що регулюють правила перетинання кордону. У результаті експорт українських товарів до Польщі за 2008 рік збільшився на $143 \%$ порівняно 3 попереднім роком, шо свідчить про позитивний вплив зазначених заходів [10].

Станом на 2017 рік, договірно-правова база між Україною та Республікою Польща налічує 129 чинних міжнародних договорів та регулює переважну більшість напрямків українсько-польської снівпраці, серед них 5 міждержавних та понад 40 міжурядових угод. Важливою складовою українсько-польської снівпраці $є$ двосторонні домовленості між суб єктами адміністративно-територіального устрою України та Республіки Польща, яких загалом налічується понад 470, що забезпечує належний розвиток двосторонньої снівпраці на рівні стратегічного партнерства [11].

Від часу входження Польщі до СС відносини між Україною і Польщею наповнилися новим змістом, посилилась їі ролі як адвоката й лобіста євроінтеграційного та євроатлантичного курсу України. Це знайшло прояв, з одного боку, у нідтримці ідей України, з іншого - у виробленні та реалізації конкретної програми снівпраці ЄС із країнами Східної Свропи [7].

Влітку 2015 року пост президента Республіки Польща посів Анджей Дуда. В Україні багато хто сприйняв його перемогу з ентузіазмом. Під час своєї виборчої кампанії А. Дуда кілька разів говорив про необхідність польської нідтримки для України. А за словами політолога В. Фесенка, між провідними політичними силами Польщі існує консенсус із приводу стратегічного характеру українсько-польських відносин, нідтримки Польщею євроінтеграційних прагнень України, тому ніяких змін у цьому плані не відбудеться [12].

Польща є найбільшим торговельним партнером України серед країн Центральної та Східної Європи. Обсяг українського експорту товарів до Польщі у 2015 році склав 2158,1 млн дол., що на $25,2 \%$ менше в порівнянни 32014 роком. Обсяг імпорту Україною товарів із Польщі у 2015 році склав 2420,9 млн дол., що на $24,3 \%$ менше у порівнянні 3 минулим роком. Негативне сальдо України у зовнішній торгівлі товарами з Польшею у 2015 році склало 262,8 млн дол. (рис. 1) [2].

Динаміку торговельних відносин України з Республікою Польщею за останні пять років відображено на рис. 1.

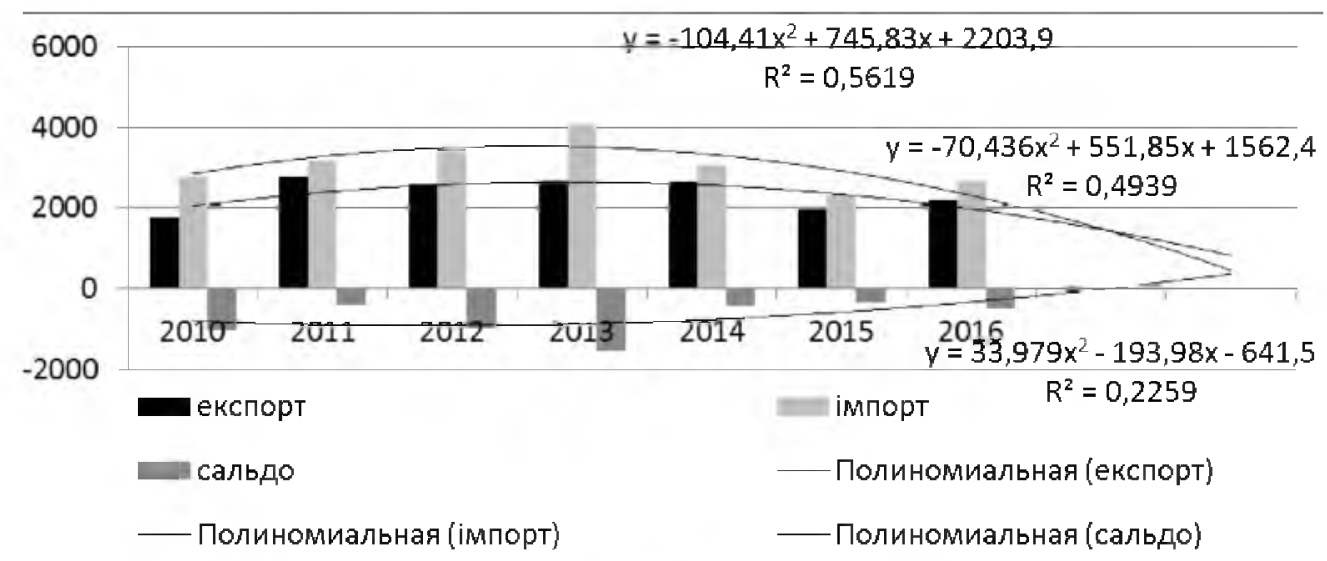

Рис. 1. Торгівля товарами між Україною та Республікоюо Польща (млы дол.) Джерело: [2] 


\section{СПІвПРАЦЯ МІЖ УКРАЇНОЮ ТА РЕСПУБЛІКОЮ ПоЛЬЩА: \\ ЕКОНОМККО-ДИНЛОМАТИЧНИЙ АСПЕКТ}

Слід відзначити зростання протягом 2016 р. обсягів двосторонньої торгівлі товарами - товарооборот України з Республікою Польща збільшився у порівнянні 3 аналогічним перюдом 2015 р. на 13,7\% і склав 4892,9 млн дол. Експорт українських товарів до Польщі у 2016 р. становив 2200,2 млн. дол., тобто зріс на $11,3 \%$ у порівнянні 3 аналогічним перюдом 2015 р., а імпорт польських товарів до України-2692,7 млн дол., тобто збільшився на 15,9\% у порівнянні з аналогічним періодом 2015 р. Від`ємне сальдо України у зовнішній торгівлі товарами з Польщею у 2016 р. склало 492,5 млн дол. Як видно з рис. 1, це сальдо було від ємним протягом усього періоду дослідження. Падіння обсягу торгівлі України з Польщею спостерігалося з 2013 року з початком “української кризи", та вже у 2016 році, з оздоровленням економіки України, товарообіг між двома країнами збільшився.

Основними групами товарів українського експорту до Польщі у 2016 році були: чорні метали (19,3\%); електричні машини (12,5\%); руди, шлаки і зола $(8,8 \%)$; деревина і вироби з деревини $(8,5 \%)$. У товарній структурі українсыкого імпорту з Польщі переважали: палива мінеральні, нафта і продукти іi перегонки $(15,9 \%)$; пластмаси, полімерні матеріали $(9,2 \%)$; електричні машини $(8,8 \%)$; реактори ядерні, котли, машини $(8,7 \%)$; засоби наземного транспорту, крім залізничного $(3,6 \%)$ [2].

Динаміку торгівлі послугами між Україною та Польщею надано на рис. 2.
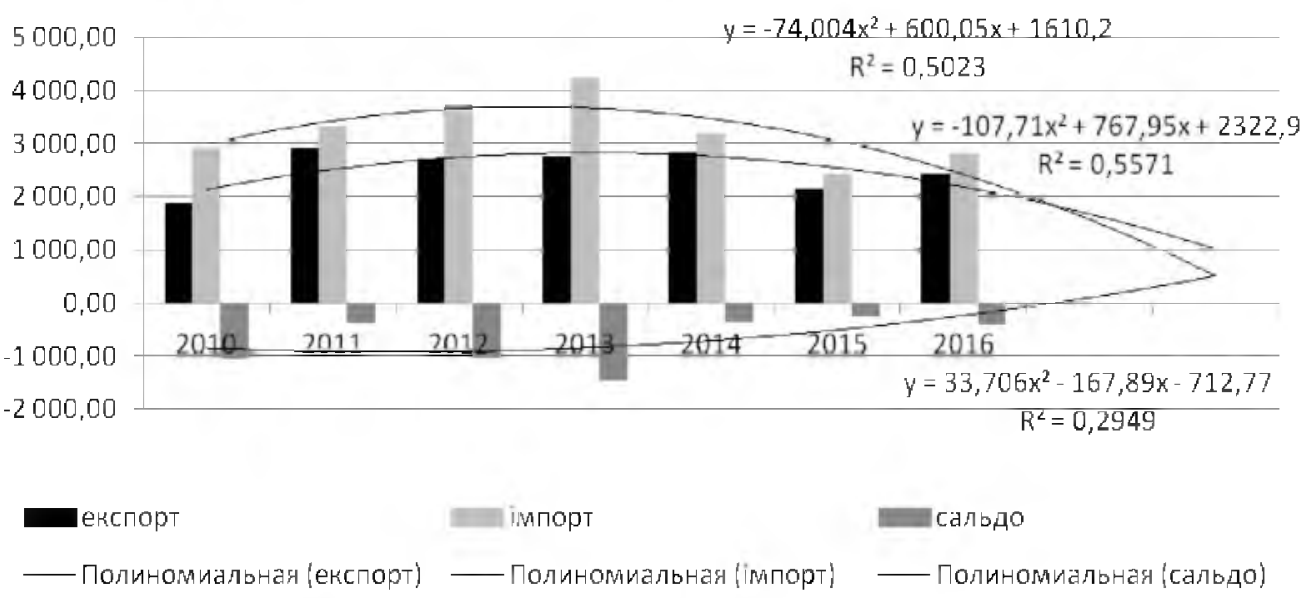

Рис. 2. Торгівля послугами між Україною та Польщею (м.лн дол.)

Джерело: [2]

Як видно з рис. 2, обсяги торгівлі послугами між Україною та Республікою Польща за результатами 2016 року у порівнянні з аналогічним періодом 2015 року збільшилися на 27,7\% і склали 358,4 млн дол. Рівень українського експорту послуг до Польщі у 2016 році становив 224,1 млн дол., збільшившись на $23,2 \%$ порівняно з попереднім роком, а польського імпорту до України - 134,3 млн дол. (збільшення на $36,1 \%$ ).

Основними видами експортних послуг України у 2016 році були: переробні $(41,8 \%)$, транспортні $(30,4 \%)$, інформаційно-телекомунікаційні $(11,9 \%)$, ділові $(7,9 \%)$ та туристичгі послуги $(4,2 \%)$. В імпорті переважали: транспортпі $(44,6 \%)$, ділові $(14,4 \%)$, фінансові $(7,4 \%)$, інформаційно-телекомунікаційні $(8,3 \%)$ та туристичпі послуги $(8,3 \%)[2]$.

Одним 3 найважливіших напрямків співпраці між Україною та Польщею $\epsilon$ інвестиційне партнерство. В Уграїні уснішно працюють підприємства і банки з польським каніталом: фабрика будівельної кераміки “ЦЦерсаніт", фабрика паркету “Барлінек”, меблева фабрика "Новий Стиль", фабрика упаковки “Кен-Пак", фабрика автозапчастин "Гнтер-Гроклін", фабрика металообробки “Полімекс-Мостосталь", банки "Кредо", "Плюс-банк" та інші. Також було нідписано меморандум про взаєморозуміння між польським "Bank Gospodarstwa Krajowego" i Державним експортно-імпортним банком України.

Українські інвестори також беруть активну участь у розвитку польської економіки. Зокрема, український канітал широко представлений у Польщі такими підприєм- 
ствами: Варшавський автомобільний завод (інвестор - “Авто-ЗАЗ”), металургійний комбінат "Гута Ченстохова" (інвестор - корпорація "lндустріальний союз Донбасу"), суднобудівний завод “стічні Гданську" (інвестор - "1СД”), "Гута поку" (інвестор "Приват"), завод освітлювальних приладів "Гелюс" (інвестор - "Іскра"), переробній завод "Т. В. Fruit Dwikozy" (інвестор - компанія "Т. В. Fruit") та інші [4; 11].

На рис. 3 показано динаміку українсько-польської інвестиційної снівпраці, яка оцінювалась за співвідношенням між прямими інвестиціями з Польші в економіку України та прямими інвестищіями з України в економіку Польщі.

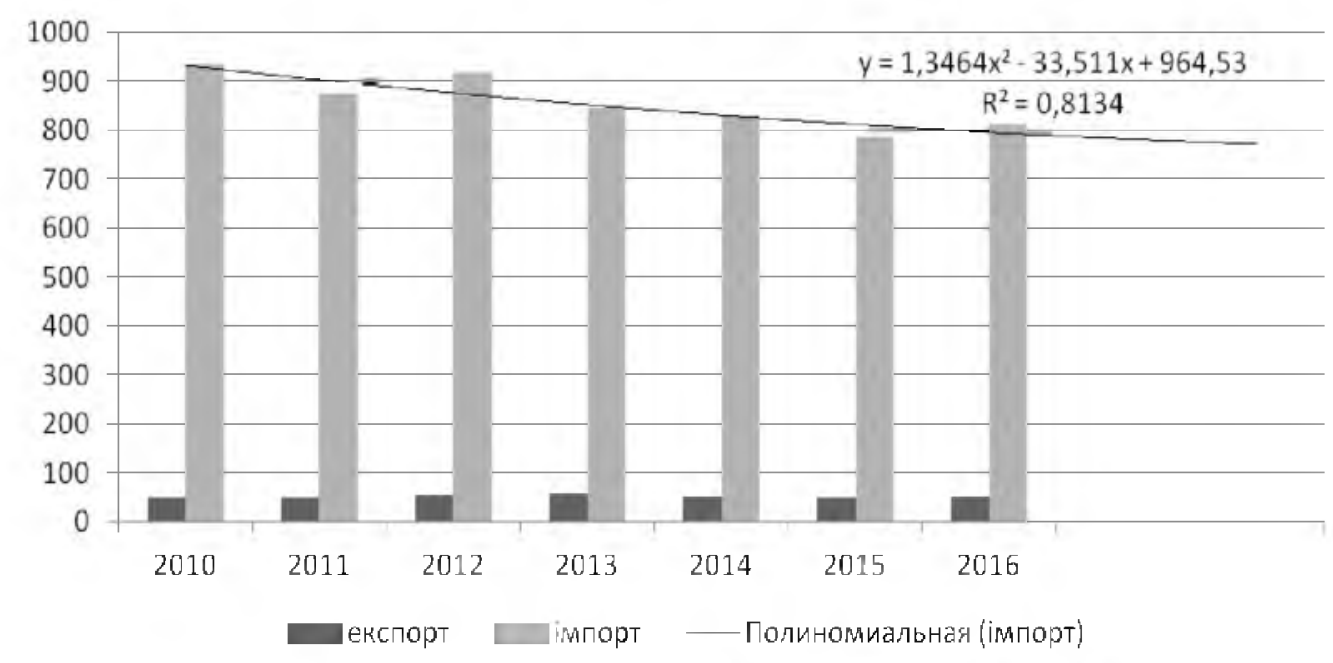

Рис. 3. Динаміка українсько-польської інвестиційної співпраці (млн дол.)

Джерело: [2]

За даними Держстату України, протягом 2016 р. сума прямих польських інвестицій, вкладених в економіку У країни, становила 25,8 млн дол., що складас $1,3 \%$ від загального обсягу іноземних інвестицій в Україну.

Впродовж 2016 р. найбільші обсяги польських інвестицін̆ залучено у такі види економічної діяльності: фінансова і страхова діяльність $(45,5 \%)$; промисловість $(33,5 \%)$; оптово-роздрібна торгівля, ремонт автотранспортних засобів і мотоциклів $(9,7 \%)$; сільське, лісове та рибне господарство $(3,9 \%)$; адміністративне та допоміжне обслуговування $(1,8 \%)[2]$.

Попри відтік польського капіталу, який можна спостерігати впродовж останніх 6 років, на сьогоднішній день в Україні уснішно працюють такі підприємства і компанії з вагомими польськими інвестиціями: фабрика будівельної кераміки "Церсаніт", деревообробна фабрика “Барлінек”, меблева фабрика “Новий Стиль", фабрика упаковки "Кен-Пак", фабрика автозапчастин "lнтер-Гроклін", завод металообробки "Полімекс-Мостосталь", підприємство з виробництва фарб "Снєжка-Україна", банківсько-фінансові установи (ПАТ “Кредобанк", ПАТ "Ідея-банк”, страхова компанія "PZU Україна"), найбільший польський ритейлер “LPP SA" та інші [11].

За даними Держстату України, у 2016 році у польсыку економіку було вкладено 0,9 млн дол. прямих українсыких інвестицін̆, що становить $7,5 \%$ від загального обсягу українських інвестицін̆ за кордоном. Втім, за наявною інформацією, обсяг реальних українських інвестицій до Республіки Польща, які з різних причин не враховуються українсыкою статистикою, перевишує 1 млрд дол. [11].

Найбільшими українськими інвестиційними проектами у Польщі є: суднобудівельний завод "Сточнє Гданське" та металургійний комбінат "Гута Ченстохова" (інвестор - “-СД"), "Гута Покуй" (інвестор - група “Приват"), завод освітлювальних приладів "Гелюс" (інвестор - "Іскра"), Мазовецький сироварний завод "Ostrowia" (iнвестор - група компаній "Milkiland"), плодопереробний завод "T.B.Fruit Dwikozy" (інвестор - компанія “Т. В. Fruit” (власник торгівельної марки “Яблуневий дар”) [2; 11$]$. 


\section{СПІвПРАЦЯ МІЖ УКРАЇНОЮ ТА РЕСПУБЛІКОН ПоЛЬЩА: ЕКОНОМККО-ДИНЛОМАТИЧНИЙ АСПЕКТ}

Висновки. Проведений аналіз українсько-польської дипломатичної сгівпраці після здобуття обома країнами політичної незалежності, а також статистичних даних про взаємну торгівлю товарами та послугами, інвестиційну снівпрацю показав, що обидві країни мають значний потенціал співпраці у різних галузях. На дипломатичному полі Республіка Польща $є$ найактивнішим захисником і лобістом євроінтеграційного та євроатлантичного курсу України. Шо стосується взаємної торгівлі, то якщо 32014 року взаємна торгівля товарами зменшувалась, то після початку оздоровлення української економіки у 2016 році спостерігається ії зростання. Утім взаємна торгівля послугами $\epsilon$ менш розвиненою, ніж торгівля товарами. Значна асиметрія на користь польських інвесторів має місце в українсько-польсыкій інвестиційній співпраці, а також спостерігається зменшення інвестицій у обох напрямах у останні роки.

\section{Список використаних джерел}

1. Гроть А., Прокопчук К. Генезис польсько-українських міждержавних економічних відносин [Електронний ресурc]. URL: http://www.stattionline.org.ua/ histori/1 13/21115-genezis-polsko-ukra\%D1\%97nskix-mizhderzhavnix-ekonomichnixvidnosin.html

2. Державна служба статистики. [Електронний ресурc]. URL: http://www.ukrstat. gov.ua/

3. Євсюкова О.В. Україна та Польща: спільні стратегічні прюритети в процесі історичних реформацій // 1нвестиції: практики та досвід. 2013. № 1. С. 68-73.

4. Слісєєва О. Стан та тенденції розвитку торгівельно-економічних відносин України та Польщі // Zeszyty Naukowe WSEI seria: EKONOMIA. 2014. № 8. C. 199-208.

5. Каррон де ля Каррьер Г. Экономическая дипломатия. Дипломат и рынок // Пер. с фр. М.: Российская политическая эншиклопедия, 2003. 296 с.

6. Киридон А. Україна-Польща: сучасний стан і перспективи узгодження зовпішньополітичних орієнтирів // 1сторія України. 2012. № 13-14. С. 3-9.

7. Киридон А. Українсько-польські відносини: "нова ера" співпраці // УкраїнаСвропа-Світ: зб. наук праць. 2010. С. 128-135.

8. Климець Н. Співпраця України та Польщі: два роки після розширення ЄС [Електронний ресурc]. URL: http://eu.prostir.ua/library/1274.html

9. Мавланов И.Р. Экономическая дипломатия: учеб. пособ. 2-е изд. М.: «Аспект Пресс», 2016. $528 \mathrm{c}$.

10. Павліха Н. В., Мрчук Ю. В. Українсько-польське еконоппічне співробітництво: сучасний стан та перспективи розвитку [Електронний ресурc]. URL: https:// ukrpolnauka.wordpress.com/2011/10/25/83/

11. Посольство України в Республіці Польща: офіційний веб-сайт [Електронний реcypc]. URL: http://poland.mfa.gov.ua/ua/ukraine-pl/legal-acts

12. Тарасенко Н. Перспективи українсько-польських відносин у контексті діяльності новообраного президента Польщі А. Дуди [Електронний ресурc]. URL: http:// nbuviap.gov.ua/index.php?option $=$ com_content\&view $=$ article\&id=1226 :ukrajinskopolski-vidnosini $\&$ catid $=8 \&$ Itemid $=350$

13. Ryeznikov V. Theoretical aspects of diplomacy, its role in international economic reations // Вісник Міжнародного Слов'янського університету. Серія "Економічні науки". 2013. Том XVI. № 1-2. C. 48-53. 
B. В. РЕЗНИКОВ,

кандидат экономических наук,

доцент кафедры межсународных экономических отномений, Харьковский начиональный университета имени В. Н. Каразина Ю. А. ЕЛФИМОВА,

бакалавр межсународных экономических отномений, Харьковский национальный университета имени В. Н. Каразина

\section{Сотрудничество между Украиной и Республикой Польша: экономико-дипломатический аспект}

Состояние и перспективы экономико-дипломатических отноиений мељду

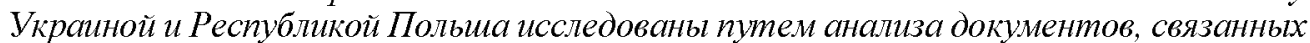
с дипломатическим и экономическим сотрудничеством между двумя странами после обретения ими политической независимости, а также статистических данных о взаимной торговле товарами и услугами и взаимных прямых инвестициях.

Ключевые слова: сотрудничество, дипломатия, торговля товарами, экспорт, импорт, инвестиции.

\section{V. RYEZNIKOV, \\ $P h D$ (Economics), Associate Professor, Department for International Economic Relations, V. N. Karazin Kharkiv National University YU. O. YELFIMOVA, Bachelor for International Economic Relations, V. N. Karazin Kharkiv National University}

\section{Cooperation of Ukraine and Republic of Poland: Economic and Diplomatic Aspects}

Poland in viewed by Ukraine as a reliable economic and political partner supporting Ukraine's intention to integrate in Europe. Therefore, facts, documents and statistical data reflecting qualitative and quantitative aspects of relations between Ukraine and Poland need to be subject to non-stop monitoring and analysis, to help in finding timely solutions for problematic issues that may occur in these countries' relations. The article 's objective is to analyze the performance and perspectives of economic and diplomatic relations between Ukraine and Republic of Poland. The analysis of documents on diplomatic and economic cooperation of the two countries after they gained political independence, and statistical data on trade in goods and services (by category) and investment flows (by data on direct investment from Ukraine to Poland and from Poland to Ukraine) shows that both countries have immense potentials for cooperation in various fields. As regards diplomatic dimension, Republic of Poland is the strongest promoter and lobbyist of the Euro-integration and Euro-Atlantic course of Ukraine. Regarding the economic cooperation, while mutual trade in goods declined in 2014 due to the economic and political crisis in Ukraine, it grew in 2016 with the recovery processes in the Ukrainian economy. Mutual trade in services is less intensive than trade in goods. Analysis of the investment cooperation shows the large asymmetry in favor of Polish investors in Ukraine and the reducing investment in both directions in the latest years.

Key words: cooperation, diplomacy, trade in goods, exports, imports, investment.

\section{Посилання на статтю:}

Рєзніков В. В., Єлф)імова Ю. О. Снівпраця мгж Україною та Республікою Польща: економіко-дипломатичний аспект // Науковий вісник Національної академії статистики, обліку та аудиту: зб. наук. пр. 2017. №3. С. 72-78. 